\title{
TINDAK PIDANA Illegal Logging MENURUT UNDANG-UNDANG NOMOR 32 TAHUN 2009 TENTANG PERLINDUNGAN DAN PENGELOLAAN LINGKUNGAN HIDUP
}

\author{
Fransiska Novita Eleanora \\ Fakultas Hukum Universitas MPU Tantular Jakarta \\ Email : vita_eleanor@yahoo.com
}

\begin{abstract}
Illegal logging refers to a series of such forestry-related acts as timber logging, transporting, and processing including both local and export-import trades, which are illegal or not in accordance with the existing laws, or the one which is environmentally harmful. Illegal logging potentially causes pollution and other environmental damage, resulting in the extinction of its inhibiting ecosystem. This research, using literary study method, is to examine the implementation of the Law No. 32 of 2009 on Environmental Protection and Management in illegal logging practices. The findings suggest that illegal logging, in fact, causes pollution and other environmental damage and thus both directly and indirectly harms the physical, chemical, and biological properties beyond the tolerated standard.
\end{abstract}

Keywords: Illegal logging, environment, damage

\begin{abstract}
Abstrak
Illegal logging kegiatan di bidang kehutanan atau yang merupakan rangkaian kegiatan yang mencakup penebangan, pengangkutan, pengolahan hingga kegiatan jual beli (termasuk ekspor-impor) kayu yang tidak sah atau bertentangan dengan aturan hukum yang berlaku, atau perbuatan yang dapat menimbulkan kerusakan hutan. Illegal logging dapat menyebabkan pencemaran dan perusakan pada lingkungan hidup, sehingga ekosistem didalamnya dapat punah. Metode Penelitian adalah Studi Pustaka, Tujuannya adalah untuk mengetahui bagaimana penerapan undang-undang Nomor 32 Tahun 2009 tentang Perlindungan dan Pengelolaan Lingkungan Hidup terhadap Illegal logging (penebangan liar). Hasilnya bahwa Illegal logging merupakan pencemaran dan perusakan lingkungan perubahan langsung dan / atau tidak langsung terhadap sifat fisik, kimia, dan / atau hayati lingkungan hidup yang melampaui kriteria baku kerusakan lingkungan hidup.
\end{abstract}

Kata Kunci : Penebangan liar, Lingkungan, Perusakan 


\section{PENDAHULUAN}

Hutan Indonesia merupakan salah satu pusat keanekaragaman hayati di dunia, dimana Indonesia merupakan urutan ketiga dari tujuh Negara yang disebut megadiversity country. Hutan Indonesia merupakan rumah bagi ribuan jenis flora dan fauna yang banyak diantara endemik di Indonesia. Dalam, kenyataannya pemanfaatan hutan alam yang telah berlangsung sejak awal 1970-an ternyata memberikan gambaran yang kurang menggembirakan untuk masa depan dunia kehutanan Indonesia.

Terlepas dari keberhasilan penghasil devisa, peningkatan pendapatan, menyerap tenaga kerja, serta mendorong pembangunan wilayah, pembangunan kehutanan melalui pemanfaatan hutan alam yang menyisakan sisi yang buram. Sisi negatif tersebut antara lain tingginya laju deforestasi yang menimbulkan kekhawatiran akan tidak tercapainya kelestarian hutan yang diperkuat oleh adanya penebangan liar (illegal logging).

Pemanfaatan dan pengelolaan sektor kehutanan adalah satu bagian yang penting dalam pengelolaan lingkungan hidup dimana telah menjadi sorotan bukan hanya secara nasional akan tetapi menjadi wacana global. Perhatian dunia internasional terhadap kelestarian hutan nampak dalam Konferensi Tingkat Tinggi (KTT) Bumi yang diadakan oleh PBB di Rio De Jeneiro pada tanggal 3 sampai 14 Juni 1992 yang juga merupakan peringatan 20 tahun Konferensi Stockholm tahun 1972.

Konferensi Tingkat Tinggi Bumi di Rio De Jeneiro menghasilkan suatu konsesus tentang beberapa bidang penting khususnya tentang prinsip-prinsip kehutanan (forest principle) yang dituangkan dalam dokumen dan perjanjian : "Non-Legally Binding Authorotative Statement of Prinsiple for a Global Consensus on the Management, Conservation and Sustainable Development of all Types of Forest" dan Bab 11 dari Agenda 21 "Combating Deforestation". Kemudian dalam pertemuan ketiga dari Komisi Pembangunan Berkelanjutan (CSD-Commission of Sustainable Development) disepakati untuk membentuk Intergovermental Panel on Forest (IPF) guna melanjutkan dialog dalam kebijakan kehutanan skala global. 
Prinsip-prinsip tentang Kehutanan tersebut di atas kemudian dijabarkan dalam Undang-Undang Kehutanan Indonesia yaitu UU No. 41 Tahun 1999 tentang Kehutanan seperti yang terlihat dalam konsideran butir a UU No. 41/1999 bahwa "hutan wajib disyukuri, diurus dan dimanfaatkan secara optimal, serta dijaga kelestariannya untuk sebesar-besarnya kemakmuran rakyat dan agar dapat dirasakan manfaatnya baik bagi generasi sekarang maupun generasi mendatang”.

Salah satu masalah yang sangat krusial dalam bidang lingkup pada sektor kehutanan ini adalah masalah penebangan liar atau yang dikenal dengan istilah “illegal logging”. Stephen Devenish, ketua Misi Forest Law Enforecment Governance and Trade dari Uni Eropa, mengatakan bahwa Penebangan Liar adalah penyebab utama kerusakan hutan di Indonesia.

Tujuan penulisan ini adalah untuk mengetahui bagaimana penerapan undang-undang Nomor 32 Tahun 2009 tentang Perlindungan dan Pengelolaan Lingkungan Hidup terhadap Illegal logging (pembalakan liar).

\section{Metode Penelitian}

Illegal logging merupakan pembalakan liar yang dapat menimbulkan perusakan lingkungan hidup dan mengakibatkan kerugian bagi masyarakat. Penelitian ini merupakan penelitian normative yang menyandarkan pada kekuatan bahan hukum sebagai literature, dalam menganalisis dan menjawab permasalahan yang diteliti.

\section{PEMBAHASAN}

\section{Ilegal Logging (Penebangan Liar)}

Pengertian illegal logging dalam peraturan perundang-undangan yang ada tidak secara eksplisit didefinisikan dengan tegas. Namun, terminologi illegal logging dapat dilihat dari pengertian secara harfiah, illegal artinya tidak sah, dilarang atau bertentangan dengan hukum. Dan Log adalah kayu gelondongan (logging artinya menebang kayu dan membawa ke tempat gergajian).

Secara umum illegal logging mengandung makna kegiatan di bidang kehutanan atau yang merupakan rangkaian kegiatan yang mencakup penebangan, pengangkutan, pengolahan hingga kegiatan jual beli (termasuk ekspor-impor) 
kayu yang tidak sah atau bertentangan dengan aturan hukum yang berlaku, atau perbuatan yang dapat menimbulkan kerusakan hutan.

Essensi yang penting dalam praktek penebangan liar (illegal logging) ini adalah perusakan hutan yang akan berdampak pada kerugian baik dari aspek ekonomi, ekologi, maupun sosial budaya dan lingkungan. Hal ini merupakan konsekuensi logis dari fungsi hutan yang pada hakekatnya adalah sebuah ekosistem yang di dalamnya mengandung tiga fungsi dasar, yaitu fungsi produksi (ekonomi), fungsi lingkungan (ekologi) serta fungsi sosial.

Dilihat dari aspek sosial, penebangan liar (illegal logging) menimbulkan berbagai konflik seperti konflik hak atas hutan, konflik kewenangan mengelola hutan antara Pemerintah Pusat dengan Pemerintah Daerah serta masyarakat adat setempat. Aspek budaya seperti ketergantungan masyarakat terhadap hutan juga ikut terpengaruh yang pada akhirnya akan merubah perspektif dan perilaku masyarakat adat setempat terhadap hutan.

Akar Permasalah dalam Illegal Logging, paling sedikit ada 4 (empat) macam yaitu :

1. Sistem Pengelolaan Hutan di Indonesia yang membuka ruang untuk terjadinya praktek illegal logging.

2. Tingkat kesejahteraan (gaji) Pejabat, Petugas dan masyarakat sekitar hutan rendah.

3. Mentalitas yang tidak baik.

4. Kontrol yang lemah, baik kontrol instansional maupun kontrol sosial.

Dampak kerusakan ekologis (lingkungan) akibat penebangan liar (illegal logging) menurut berbagai penelitian yang dilakukan oleh para pakar pemerhati lingkungan dan kehutanan bahwa berbagai bencana alam yang terjadi, disinyalir sebagai akibat dari kerusakan hutan sebagai dampak dari penebangan liar (illegal logging). Selain bencana alam, penebangan liar (illegal logging) ini juga menimbulkan kerusakan flora dan fauna serta punahnya spesies langka. ${ }^{1}$

${ }^{1}$ Emil Salim, Ratusan Bangsa Merusak Satu Bumi, Buku Kompas, 2007, hal. 23-28 
Dampak kerugian ekonomi yang ditanggung oleh Negara dapat dilihat dari penelitian yang dilakukan oleh David W. Brown pengamat ekonomi kehutanan dari Departement For International Development (DFID) yang mengkalkulasikan kerugian finansial yang ditanggung pemerintah akibat perdagangan kayu liar (illegal timber trading) adalah sebesar US \$ 1,632 milliar per tahun dan kerugian akibat penebangan liar (illegal logging) di Indonesia mencapai US \$ 5,7 miliar per tahun. Angka tersebut diperoleh dari perhitungan 68 juta meter kubik kayu illegal yang dikonsumsi pabrik kayu dalam negeri untuk diolah senilai US \$ 4,08 miliar dikalikan dengan pajak yang harus dibayar setiap meter kubik kayu, sebesar US $\$ 24$.

\section{Hak Atas Lingkungan Hidup Yang Baik dan Sehat}

Secara konstitusional, hak atas lingkungan dalam hukum nasional Indonesia tercantum dalam:

1) Alinea keempat Pembukaan UUD 1945: ...membentuk suatu pemerintah Negara Indonesia yang melindungi segenap bangsa Indonesia... serta dikaitkan dengan Hak Penguasaan Negara atas bumi, air dan kekayaan yang terkandung di dalamnya untuk kemakmuran rakyat;

2) Amandemen UUD 1945 Pasal 28H (1) menyebutkan Setiap orang berhak hidup sejahtera lahir dan batin, bertempat tinggal dan mendapatkan lingkungan hidup yang baik dan sehat serta berhak memperoleh palayanan kesehatan

3) Piagam HAM yang merupakan bagian tak terpisahkan dari TAP MPR No. XVII/MPR/1998 yang ditetapkan oleh Sidang Istimewa MPR tahun 1998 diantaranya menyatakan, bahwa manusia adalah mahluk Tuhan Yang Maha Esa yang berperan sebagai pengelola dan pemelihara alam secara seimbang dan serasi dalam ketaatan kepada-Nya. Manusia dianugerahi hak asasi dan memiliki tanggung jawab serta kewajiban untuk menjamin keberadaan, harkat, dan martabat kemuliaan kemanusiaan serta menjaga keharmonisan kehidupan; 
4) UU No.23/1997 Pasal 5 (1) Setiap orang mempunyai hak yang sama atas lingkungan hidup yang baik dan sehat dan Pasal 8 (1) Sumber daya alam dikuasai oleh negara dan dipergunakan untuk sebesar-besarnya bagi kemakmuran rakyat, serta pengaturannya ditentukan oleh pemerintah;

5) UU No.39/1999 tentang HAM Pasal 3, menyatakan masyarakat berhak atas lingkungan hidup yang baik dan sehat

\section{PENCEMARAN DAN PERUSAKAN LINGKUNGAN HIDUP}

Pencemaran lingkungan hidup adalah masuknya atau dimasukkannya makhluk hidup, zat, energi, dan/atau komponen lain ke dalam lingkungan hidup oleh kegiatan manusia sehingga kualitasnya turun sampai ke tingkat tertentu yang menyebabkan lingkungan hidup tidak dapat berfungsi sesuai dengan peruntukannya (Pasal 1 angka 12 UU No. 32/2009).

Perusakan lingkungan hidup adalah tindakan yang menimbulkan perubahan langsung atau tidak langsung terhadap sifat fisik dan/atau hayatinya yang mengakibatkan lingkungan hidup tidak berfungsi lagi dalam menunjang

Undang-undang Dasar 1945, memberikan dasar hukum yang kuat bagi pengelolaan sumber daya alam hayati, seperti disebut dalam pembukaan dan khususnya pada pasal 33 ayat 3 yang menyatakan dengan tegas bahwa kekayaan alam indonesia, termasuk sumber daya alam hayati yang ada didalamnya dikuasai oleh negara dan digunakan sebesar-besarnya untuk kemakmuran rakyatnya.

Asas pelestarian yang bersifat ekologis dengan sudut pandang yang menyeluruh secara tegas ditemukan dalam UU No. 23 tahun 1997 (diperbaharui dengan UU No. 32/2009 tentang Pengelolaan Lingkungan Hidup), pasal 3 undang-undang ini dengan tegas menyatakan bahwa asas pelestarian kemampuan lingkungan merupakan landasan hukum bagi pembangunan yang berkesinambungan (sustainable development) dan dalam Pasal 12 UULH-82 diatur tentang konservasi sumber daya alam hayati dan ekosistem.

Undang-undang No.32/2009 memberikan pengertian konservasi dalam pasal 1 butir 15 : "Konservasi sumber daya alam adalah pengelolaan sumber daya alam tak terbaharui untuk menjamin pemanfaatannya secara bijaksana dan 
sumber daya alam yang terbaharui untuk menjamin kesinambungan ketersediaannya dengan tetap memelihara dan meningkatkan kualitas nilai serta keanekaragamannya".

Dimana dari uraian tersebut menegaskan adanya tiga kegiatan untuk melakukan konservasi alam hayati dan ekosistemnya untuk menetapkan ukuranukuran yang pasti tentang apa yang disebut pencemaran lingkungan dan perusakan lingkungan yaitu :

a. Perlindungan sistem penyangga kehidupan,

b. Pengawetan keanekaragaman jenis tumbuhan dan satwa beserta ekosistemnya,

c. Pemanfaatan secara lestari sumber daya alam hayati dan ekosistemnya.

Terkait dengan perusakan lingkungan hidup secara tegas disebutkan dalam pasal 1 butir 14 UU PLH No. 32/2009 yaitu bahwa " perusakan lingkungan hidup adalah tindakan yang menimbulkan perubahan langsung terhadap sifat fisik dan/atau hayatinya yang mengakibatkan lingkungan hidup tidak berfungsi lagi dalam menunjang pembangunan berkelanjutan”.

Merusak hutan yang berdampak pada kerusakan lingkungan adalah merupakan suatu kejahatan sebagaimana dijelaskan dalam pasal 48 UU No. 32/2009 bahwa "tindak pidana sebagaimana dimaksud dalam bab ini adalah kejahatan”. Bab yang dimaksud dalam pasal tersebut adalah Bab IV UU No.32/2009 tentang ketentuan pidana, yang didalamnya dirumuskan tentang ketentuan pidana terhadap perbuatan yang mengakibatkan pencemaran dan/atau perusakan lingkungan.

Perusakan hutan adalah merupakan salah satu bentuk perusakan lingkungan, oleh karena itu maka perusakan hutan adalah merupakan suatu kejahatan. Salah satu bentuk perusakan hutan itu adalah penebangan liar (illegal logging).

Terjadinya kegiatan penebangan liar di Indonesia didasari oleh beberapa permasalahn yang terjadi, yaitu :

\section{a. Masalah sosial dan ekonomi}


Kondisi kemiskinan kemudian dimanfaatkan oleh para pemodal yang tidak bertanggung jawab, yang menginginkan keuntungan cepat dengan menggerakan masyarakat melakukan penebangan liar.

\section{b. Kelembagaan}

Sistem pengusahaan melalui $\mathrm{HPH}$ telah membuka celah celah dilakukannya penebangan liar, disamping lemahnya pengawasan instansi kehutanan. Selain itu penebangan hutan melalui pemberian hak penebangan hutan skala kecil oleh daerah telah menimbulkan peningkatan fragmentasi hutan.

\section{c. Kesenjangan ketersediaan bahan baku}

Terdapat kesenjangan penyediaan bahan baku kayu bulat untuk kepentingan industri dan kebutuhan domestic yang mencapai sekitar 37 juta $\mathrm{m} 3$ per tahun telah mendorong terjadinya penebangan kayu secara liar. Disamping itu terdapat permintaan kayu dari luar negeri, yang mengakibatkan terjadinya penyelundupan kayu daam jumlah besar. Dibukanya kran ekspor kayu bulat menyebabkan sulinya mendeteksi aliran kayu illegal lintas batas.

\section{d. Lemahnya koordinasi}

Kelemahan koordinasi antara lain terjadi alam hal pemberian ijin industry pengolahan kayu antara instansi perindustrian an instansi kehutanan serta alam hal pemberian ijin eksplorasi dan eksploitasi pertambangan antara instansi pertambangan dan instansi kehutanan serta instansi terkait seperti kepolisian, kejaksaan dan pengadilan.

\section{e. Kurangnya komitmen dan kelemahan law enforcement}

Rendahnya komitmen terhadap kelestarian hutan menyebabkan aparat pemerintah baik pusat maupun daerah, eksekutif, legislative maupun yudikatif, banyak terlibat dalam praktek KKN yang berkaitan dengan penebangan secara liar. Penegak hokum bias "dibeli" sehingga para koruptor pelaku pencurian kayu dapat terus lolos dari hukuman. 


\section{SEBAB}

Illegal logging atau pembalakan liar atau penebangan liar adalah kegiatan penebangan, pengangkutan dan penjualan kayu yang tidak sah atau tidak memiliki izin dari otoritas setempat. Secara praktek, illegal logging dilakukan terhadap areal hutan yang secara prinsip dilarang. Di samping itu, praktek illegal logging dapat pula terjadi selama pengangkutan, termasuk proses ekpor dengan memberikan informasi salah ke bea cukai, sampai sebelum kayu dijual di pasar legal. ${ }^{2}$

Illegal logging dapat disebabkan oleh beberapa hal: pertama, tingginya permintaan kebutuhan kayu yang berbanding terbalik dengan persediaannya. Dalam kontek demikian dapat terjadi bahwa permintaan kebutuhan kayu sah (legal logging) tidak mampu mencukupi tingginya permintaan kebutuhan kayu. Hal ini terkait dengan meningkatnya kebutuhan kayu di pasar internasional dan besarnya kapasitas terpasang industri kayu dalam negeri/konsumsi lokal. Tingginya permintaan terhadap kayu di dalam dan luar negeri ini tidak sebanding dengan kemampuan penyediaan industri perkayuan (legal logging). Ketimpangan antara persediaan dan permintaan kebutuhan kayu ini mendorong praktek illegal logging di taman nasional dan hutan konservasi.

Kedua, tidak adanya kesinambungan antara Peraturan Pemerintah No. 21 Tahun 1970 yang mengatur tentang Hak Pengusahaan Hutan mengenai Sistem Silvikultur dan Daur Tanaman Pokok Dalam Pengelolaan Hutan Produksi. Ketidaksinambungan kedua peraturan perundang-undangan tersebut terletak pada ketentuan mengenai jangka waktu konsesi hutan, yaitu 20 tahun dengan jangka waktu siklus Tebang Pilih Tanam Indonesia (TPTI), khususnya untuk hutan produksi yangditetapkan 35 tahun.Hal demikian menyebabkan pemegang HPH tidak menaati ketentuan TPTI. Pemegang HPH tetap melakukan penebangan meskipun usia pohon belum mencapai batas usia yang telah ditetapkan dalam TPTI. Akibatnya, kelestarian hutan menjadi tidak terjaga akibat illegal logging.

\footnotetext{
${ }^{2}$ Indro Sugianto, Manual Investasi Illegal Logging, Indonesian Center For Environmental Law, Jakarta, 2006, hal. 15-18
} 
Ketiga, lemahnya penegakan dan pengawasan hukum bagi pelaku tindak pidana illegal logging. Selama ini, praktekillegal logging dikaitkan dengan lemahnya penegakan hukum, di mana penegak hukum hanya berurusan dengan masyarakat lokal atau pemilik alat transportasi kayu. Sedangkan untuk para cukong kelas kakap yang beroperasi di dalam dan di luar daerah tebangan, masih sulit untuk dijerat dengan ketentuan-ketentuan hukum yang berlaku. Bahkan beberapa pihak menyatakan"untuk menjerat pelaku utama illegal logging, melainkan hanya menangkap pelaku lapangan. Di samping itu, disinyalir adanya pejabat pemerintah yang korup yang justru memiliki peran penting dalam melegalisasi praktek illegal logging.

Keempat, tumpang tindih kebijakan pemerintah pusat dengan pemerintah daerah. Hak Pegusahaan Hutan selama ini berada di bawah wewenang pemerintah pusat, tetapi di sisi lain, sejak kebijakan otonomi daerah diberlakukan pemerintah daerah harus mengupayakan pemenuhan kebutuhan daerahnya secara mandiri. Kondisi ini menyebabkan pemerintah daerah melirik untuk mengeksplorasi berbagai potensi daerah yang memiliki nilai ekonomis yang tersedia di daerahnya, termasuk potensi ekonomis hutan. Dalam kontek inilah terjadi tumpang tindih kebijakan pemerintah pusat dengan pemerintah daerah.

Di sisi lain pemerintah daerah mengeluarkan kebijakan untuk mengeksplorasi kekayaan alam daerahnya, termasuk hutan guna memenuhi kebutuhan daerahnya. Tumpang tindih kebijakan ini telah mendorong eksploitasi sumber daya alam kehutanan. Tekanan hidup yang dialami masyarakat daerah yang tinggal di dalam dan sekitar hutan mendorong mereka untuk menebang kayu, baik untuk kebutuhan sendiri maupun untuk kebutuhan pasar melalui tangan para pemodal.

\section{AKIBAT}

Praktek illegal logging sudah barang tentu memiliki ekses negatif yang sangat besar. Secara kasat mata ekses negatifillegal logging dapat diketahui dari rusaknya ekosistem hutan. Rusaknya ekosistem hutan ini berdampak pada menurunnya atau bahkan hilangnya fungsi hutan sebagai penyimpan air, 
pengendali air yang dapat mencegah banjir juga tanah longsor. Sehingga rentan terhadap bencana kekeringan, banjir maupun tanah longsor. Di samping itu, illegal logging juga menghilangkan keanekaragaman hayati, berkurangnya kualitas dan kuantitas ekosistem danbiodiversity, dan bahkan illegal logging dapat berperan dalam kepunahan satwa alam hutan Indonesia.

Dari sisi ekonomis, illegal logging telah menyebabkan hilangnya devisa negara. Menurut Walhi, hasil illegal logging di Indonesia pertahunnya mencapai 67 juta meter kubik dengan nilai kerugian sebesar Rp 4 triliun bagi Negara. Di samping itu, data Kementerian Kehutanan menunjukkan bahwa dalam kurun waktu 2004 hingga 2010, kerugian Indonesia akibat illegal logging mencapai 180 triliun.

\section{PENANGGULANGAN}

Terdapat beberapa alternatif cara untuk menganggulangi atau paling tidak meminimalisir praktek illegal logging. Pertama, telah diungkapkan sebelumnya bahwa praktek illegal logging disebabkan oleh meningkatnya permintaan kayu di pasar internasional. Dan sebagian besar kayu yang dipasarkan di dunia internasional adalah kayu hasil illegal logging. Hal ini berarti bahwa illegal logging turut melibatkan dunia internasional. Dengan demikian penanggulangan illegal logging harus dilakukan dengan melakukan kerjasama dengan dunia internasional, seperti yang telah dilakukan Indonesia dengan Inggris lewat penandatanganan nota kesepahaman Forest Law Enforcement and Governance (FLEG). Hal terpenting dalam nota kesepemahaman tersebut adalah pemenuhan standar legalitas (keabsahan) kayu yang diperdagangkan. Keabsahan kayu harus dilihat, baik oleh hukum negara maupun hukum adat di mana kayu tersebut tumbuh.

Kedua, terkait dengan lemahnya penegakan dan pengawasan hukum, disinyalir karena UU Kehutanan dianggap tidak memiliki "taring" untuk menjerat pelaku utama illegal logging, melainkan hanya menangkap pelaku lapangan. Oleh karena itu, tindak pidana illegal logging ini harus dibentuk dalam undang-undang sendiri tentang illegal logging. Alasannya, selain karena UU Kehutanan dianggap 
tidak memiliki "taring” untuk menjerat pelaku utama illegal logging,juga karena tindak pidana illegal logging dapat dikategorikan sebagai kejahatan luar biasa. Selain merugikan keuangan negara, illegal logging juga setidaknya memiliki empat tindak pidana, yaitu: perusakan lingkungan, korupsi, pencucian uang, dan pelanggaran kepabeanan. Sehingga penanganannya pun harus luar biasa, termasuk memasukkan illegal logging dalam undang-undang khusus di luar UU Kehutanan.

Ketiga, terkait dengan tumpang tindih kebijakan pemerintah pusat dengan pemerintah daerah menyangkut kehutanan. Dalam era otonomi daerah sekarang ini, managemen hubungan pusat daerah harus dikelola dengan baik, sehingga terjadi sinkronisasi fungsi antara pusat dan daerah. Harus dipahami bahwa dalam konsep otonomi, daerah memiliki wewenang dominan di daerahnya dibanding pusat, maka harus ditegaskan bahwa kebijakan yang menyangkut daerah, termasuk kebijakan dalam rangka kekayaan daerah (termasuk di dalamnya hutan), harus berada di tangan daerah dalam batas-batas tertentu kewenangan. Di samping itu, harus dibentuk suatu mekanisme pengawasan pelaksanaan kebijakan daerah, sehingga daerah tidak absolut dalam menentukan kebijakannya, sehingga prinsip check and balance terjadi antara pusat dan daerah.

Keempat, penanggulangan illegal logging dengan pendekatan ekonomi, yaitu dengan menjalin kerjasama dengan Bank Indonesia (BI) dan Pusat Pelaporan dan Analisis Transaksi Keuangan (PPATK) dan Komisi Pemberantasan Korupsi (KPK). Sinergi dengan ketiga institusi tersebut untuk menanggulangi illegal logging dilakukan dengan pelacakan terhadap uang hasil illegal logging. Dari sisi legal, BI telah mensyaratkan prinsip Know Your Customer, yang mengharuskan perbankan mengenali nasabahnya. ${ }^{3}$

Jika ada transaksi di atas Rp. 100 juta sehari, nasabah harus menjelaskan asal-usul uang, atau adanya Tindak Pidana Pencucian Uang, yang memungkinkan menjerat illegal logging sebagai tindak pidana. Dengan demikian, pendekatan anti-money laundering regime untuk menekan laju illegal logging dapat diterapkan. Kemudian, PPATK bisa memulai membuat peraturan yang

\footnotetext{
${ }^{3}$ Achmad Santosa, Membentuk Pemerintahan Peduli Lingkungan Dan Rakyat, Indonesian Center For Environmental Law, Jakarta, 2000, hal. 53
} 
mewajibkan lembaga penyedia jasa keuangan (bank, pasar modal, asuransi, dan money changer) membuat laporan rutin tentang transaksi-transaksi yang dicurigai. Langkah ini harus diikuti dengan penerbitan pedoman bagaimana perbankan bisa mengenali transaksi hasil illegal logging.

Pada tahap awal, langkah ini akan terbantu bila PPATK membuat semacam risk profile: high risk country, location, and customer. High risk countrymenunjukkan negara-negara yang berpotensi tinggi melakukan tindak pidana pencucian uang. Dengan demikian, terhadap negara-negara tersebut diterapkan prinsip kehati-hatian dalam melakukan transaksi. High risk locationmenunjukkan daerah-daerah di Indonesia yang kerap kali menjadi daerah keluar masuk kayu ilegal. High risk customermenunjukkan identitas-identitas nasabah yang acapkali bertindak sebagai penyokong tindak pidana illegal logging.

\section{Dampak Ilegal Logging}

Kegiatan penebangan kayu secara liar (illegal logging) tanpa mengindahkan kaidah-kaidah manajemen hutan untuk menjamin kelestarian sumber daya hutan telah menyebabkan berbagai dampak negatif dalam berbagai aspek, sumber daya hutan yang sudah hancur selama masa orde baru, kian menjadi rusak akibat maraknya penebangan liar dalam jumlah yang sangat besar. Kerugian akibat penebangan liar memiliki dimensi yang luas tidak saja terhadap masalah ekonomi, tetapi juga terhadap masalah sosial, budaya, politik dan lingkungan.

Dari perspektif ekonomi kegiatan illegal logging telah mengurangi penerimaan devisa negara dan pendapatan negara. Berbagai sumber menyatakan bahwa kerugian negara yang diakibatkan oleh illegal logging, mencapai Rp.30 trilyun per tahun. Permasalahan ekonomi yang muncul akibat penebangan liar bukan saja kerugian finansial akibat hilangnya pohon, akan lebih berdampak pada ekonomi dalam arti luas, seperti hilangnya kesempatan untuk memanfaatkan keragaman produk di masa depan (opprotunity cost).

Dari segi sosial budaya dapat dilihat munculnya sikap kurang bertanggung jawab yang dikarenakan adanya perubahan nilai dimana masyarakat pada 
umumnya sulit untuk membedakan antara yang benar dan salah serta antara baik dan buruk. Hal tersebut disebabkan telah lamanya hukum tidak ditegakkan ataupun kalau ditegakkan, sering hanya menyentuh sasaran yang salah. Perubahan nilai ini bukanlah sesuatu yang mudah untuk dikembalikan tanpa pengorbanan yang besar.

Kerugian dari segi lingkungan yang paling utama adalah hilangnya sejumlah tertentu pohon sehingga tidak terjaminnya keberadaan hutan yang berakibat pada rusaknya lingkungan, berubahnya iklim mikro, menurunnya produktivitas lahan, erosi dan banjir serta hilangnya keanekaragaman hayati. Kerusakan habitat dan terfragmentasinya hutan dapat menyebabkan kepunahan suatu spesies termasuk fauna langka.

Ironisnya AMDAL yang diharapkan sebagai perangkat kebijakan yang dipersiapkan untuk mengurangi dampak lingkungan suatu kegiatan sejak tahap perencanaan kegiatan dan bertujuan mencegah laju pencemaran dan kerusakan lingkungan belum dapat diharapkan. Untuk melihat sejauh mana penerapan AMDAL dalam era otonomi daerah, Kementrian Lingkungan hidup telah mengevaluasi terhadap 75 dokumen AMDAL. Evaluasi ini menunjukkan sebagian besar dokumen AMDAL gagal menyajikan substansi esensial yang harus ada di dalamnya dan tidak konsisten dalam mengevaluasi dampak yang dikaji. Sebanyak $68 \%$ dokumen AMDAL tersebut dikategorikan jelek. ${ }^{4}$

Hanya sebagian kecil dokumen yang menunjukkan mutunya bagus, sehingga dapat digunakan sebagai bahan pertimbangan dalam pengambilan keputusan yang baik. Hasil evaluasi tersebut menunjukkan, meski-pun secara kelembagaan institusi AMDAL telah telah mencapai taraf mapan, tetapi masih memerlukan perbaikan terus menerus agar lebih meningkatkan peranan AMDAL dalam pengelolaan lingkungan hidup.

\footnotetext{
${ }^{4}$ Suryanto dkk, Illegal Logging : Sebuah Misteri Dalam Sistem Pengrusakan Hutan Indonesia, Balai Litbang Kehutanan, Kalimantan, 2006, hal. 48
} 


\section{Upaya Mengatasi Illegal Logging}

Penanggulangan illegal logging tetap harus diupayakan hingga kegiatan illegal logging berhenti sama sekali sebelum habisnya sumber daya hutan dimana terdapat suatu kawasan hutan tetapi tidak terdapat pohon-pohon di dalamnya. Penanggulangan illegal logging dapat dilakukan melalui kombinasi dari upayaupaya pencegahan (preventif), penanggulangan (represif) dan upaya monitoring (deteksi), antara lain :

1. Deteksi terhadap adanya kegiatan penebangan liar yakni, Kegiatan-kegiatan deteksi mungkin saat ini telah dilakukan, namun walaupun diketahui atau ada dugaan terjadi kegiatan illegal logging tindak lanjutnya tidak nyata. Meski demikian aksi untuk mendeteksi adanya illegal logging tetap harus terus dilakukan, namun harus ada komitmen untuk menindaklanjuti dengan proses penegakan hukum yang tegas dan nyata di lapangan.

2. Tindak prefentif untuk mencegah terjadinya illegal logging Tindakan preventif merupakan tindakan yang berorientasi ke depan yang sifatnya strategis dan merupakan rencana aksi jangka menengah dan jangka panjang, namun harus dipandang sebagai tindakan yang mendesak untuk segera dilaksanakan. Kegiatan preventif dapat dilakukan melalui : Pembangunan kelembagaan (Capacity Building) yang menyangkut perangkat lunak, perngkat keras dan SDM termasuk pemberian reward and punishment.

3. Tindakan supresi (represif). Tindakan represif merupakan tindakan penegakan hukum mulai dari penyelidikan, penyidikan sampai ke pengadilan. Untuk itu harus ada kesamaan persepsi antara masing-masing unsur penegak hukum yaitu penyidik (Polri dan PPNS), jaksa penuntut dan hakim. Karena besarnya permasalahan ilegal logging, tindakan represif harus mampu menimbulkan efek jera sehinga pemberian sanksi hukum harus tepat.

Dalam Undang-undang Nomor 32 Tahun 2009 sanksi pidana dengan penarikan izin usaha dan pidana penjara lebih dihindari para pengusaha atau pelaku pengerusakan lingkungan. Memang dalam perudang-undangan yang ada saat ini lebih mengedepankan denda yang besar daripada pengembalian fungsi 
hutan dan lingkungan. Hal ini yang menyebabkan para pelaku usaha dari awal mendapatkan izin langsung memaksimalkan produksi untuk mengumpulkan keuntungan.

Apabila terjadi pengrusakan lingkungan yang tidak disengaja dapat diganti rugi dengan sejumlah dana denda. Karena masalah hutan dan lingkungan saat ini lebih didomonasi para pemegang izin yang melanggar atau tidak mematuhi hukum yang diberlakukan atas dirinya berdasarkan izin tersebut. Artinya mereka melakukan perbuatan yang tidak diatur dalam izin yang diberikan.

Hal yang sering terjadi, dengan gampangnya para pemberi izin dengan merubah fungsi hutan, misalnya dari Hutan Lindung dan Hutan taman nasional menjadi hutan industri, yang berakibat fatal dengan banyaknya hutan yang seharusnya dipertahankan dan diatur dengan undang-undang untuk itu, dikelola oleh pengusaha. Apabila tetap terjadi perubahan fungsi dan jenis hutan, tidaklah menutup kemungkinan hutan yang ada di Indonesia saat ini akan habis.

\section{PENERAPAN UNDANG-UNDANG LINGKUNGAN HIDUP UNTUK PERLINDUNGAN HUTAN INDONESIA}

Undang-undang Lingkungan Hidup diarahkan agar hutan dan semua Sumber Daya Alam yang ada di bumi Indonesia dapat perlindungan dengan segala aturan yang telah ada saat ini. Berbicara tentang hukum yang berlaku untuk mengatasi segala permasalahan permasalahan, harus dilihat dari tiga sisi, yakni sisi substansi hukum, aparatur hukum yang ada dalam setiap proses yang ada serta budaya hukum yang hidup dalam masyarakat itu sendiri. Selanjutnya apakah hukum itu telah diterapkan dengan baik atau tidak?. Artinya pada saat salah satu dari ketiga hal itu tidak terpenuhi maka penerapan hukum yang diharapkan tidaklah akan berjalan sesuai dengan harapan.

Sekian banyak penyimpangan fungsi hutan di Indonesia, dari hutan lindung diubah fungsi hutannya menjadi hutan industri. Beberapa hutan lindung yang ada di Indonesia telah rusak dan menjadi permasalahan lingkungan. Pengerusakan hutan yang terjadi seringkali mengakibatkan efek sangat besar bagi kehidupan sehari-hari masyarakat di lingkungan hutan tersebut. Mulai dari 
terjadinya kekeringan, longsor, dan erosi dan paling parah masyarakat tidak dapat melanjutkan kehidupan secara layak akibat kerusakan yang terjadi seperti pertanian, perikanan darat, dan kehidupan sehari-hari yang terganggu. ${ }^{5}$

Dari sekian banyak fakta nyata mengenai pengrusakan hutan yang terjadi di Indonesia sering ditindak tidak sesuai dengan harapan masyarakat umum. Masyarakat lebih mengharapkan fungsi hutan yang telah dirusak dikembalikan daripada sekedar pemidanaan dan denda yang dikenakan terhadap pelaku pengrusakan hutan. Ini karena masyarakat lebih membutuhkan air, tanah, hawa sejuk, udara segar, tanah tidak longsor, dan keindahan alam seperti sebelum pengerusakan lingkungan hutan. Artinya pemerintah harus dapat menghukum para perusak hutan agar mengembalikan hutan sebagaimana mestinya dan memberikan efek jera terhadapnya. Apabila sekedar pengembalian kerugian negara dalam materi, tidaklah memberikan efek jera karena para pengusaha tidak sulit untuk mengembalikan uang negara.

Dalam Undang-undang Nomor 32 Tahun 2009 sanksi pidana dengan penarikan izin usaha dan pidana penjara lebih dihindari para pengusaha atau pelaku pengerusakan lingkungan. Memang dalam perudang-undangan yang ada saat ini lebih mengedepankan denda yang besar daripada pengembalian fungsi hutan dan lingkungan. Hal ini yang menyebabkan para pelaku usaha dari awal mendapatkan izin langsung memaksimalkan produksi untuk mengumpulkan keuntungan.

Apabila terjadi pengrusakan lingkungan yang tidak disengaja dapat diganti rugi dengan sejumlah dana denda. Karena masalah hutan dan lingkungan saat ini lebih didomonasi para pemegang izin yang melanggar atau tidak mematuhi hukum yang diberlakukan atas dirinya berdasarkan izin tersebut. Artinya mereka melakukan perbuatan yang tidak diatur dalam izin yang diberikan.

Hal yang sering terjadi, dengan gampangnya para pemberi izin dengan merubah fungsi hutan, misalnya dari Hutan Lindung dan Hutan Taman Nasional menjadi hutan industri, yang berakibat fatal dengan banyaknya hutan yang

\footnotetext{
${ }^{5}$ Sukardi, Illegal Logging Dalam Perspektif Hukum Pidana (Kasus Papua), Universitas Atmajaya Yogyakarta, 2005, hal. 32-35
} 
seharusnya dipertahankan dan diatur dengan undang-undang untuk itu, dikelola oleh pengusaha. Apabila tetap terjadi perubahan fungsi dan jenis hutan, tidaklah menutup kemungkinan hutan yang ada di Indonesia saat ini akan habis.

\section{Solusi untuk mengatasi Illegal Logging}

1. Reboisasi atau penanaman kembali hutan yang gundul.

2. Menerapkan sistem tebang pilih dalam menebang pohon.

3. Manipulasi lingkungan serta pengendalian hama dan penyakit juga bisa dilakukan untuk memulihkan kembali hutan di Indonesia.

4. Penanaman hutan secara intensif menjadi pilihan terbaik karena bisa diprediksi. Sehingga,

5. Kebutuhan kayu bisa diperhitungkan tanpa harus merusak habitat hutan alam yang masih baik.

6. Menerapkan sanksi yang berat bagi mereka yang melanggar ketentuan mengenai pengelolaan hutan. Misalkan dengan upaya pengawasan dan penindakan yang dilakukan di TKP (tempat kejadian perkara), yaitu di lokasi kawasan hutan dimana tempat dilakukannya penembangan kayu secara illegal.

7. Upaya lain yang juga dapat dilakukan adalah dengan mengoptimalkan pospos tempat penarikan retribusi yang banyak terdapat di pinggir-pinggir jalan luar kota. Petugas pos retribusi hanya melakukan pekerjaan menarik uang dari truk yang membawa kayu, hanya sekedar itu. Seharusnya di samping melakukan penarikan uang retribusi juga sekaligus melakukan pengecekan terhadap dokumen yang melegalkan pengangkutan kayu. ${ }^{6}$

8. Menelusuri terminal/tujuan akhir dari pengangkutan kayu illegal, dan biasanya tujuan itu adalah perusahaan atau industri yang membutuhkan bahan baku dari kayu. Upaya ini dirasa cukup efektif untuk menanggulangi perbuatan-perbuatan illegal logging. Perusahaan atau industri seperti ini dapat dituding telah melakukan “penadahan”.Perbuatan menampung terhadap kayu-

\footnotetext{
${ }^{6}$ Rahmat Ruhayana, Partisikencana Dan Pelestarian Lingkungan Hidup, Mitra Gama Widya, Yogyakarta, 2008, hal. 22
} 
kayu illegal oleh perusahaan, yang dalam bahasa hukum konvensional KUHP disebut sebagai penadahan tersebut, dapat dikategorikan sebagai kejahatan korporasi (corporate crime)

\section{PERAN SERTA MASYARAKAT DALAM PENGELOLAAN LINGKUNGAN HIDUP}

Hakikat peran serta masyarakat dalam pengelolaan lingkungan hidup dapat terwujud dalam bentuk:

1) Turut memikirkan dan memperjuangkan nasib sendiri dengan memanfaatkan berbagai potensi yang ada di masyarakat;

2) Tidak menyerahkan penentuan nasibnya kepada orang lain, seperti kepada pemimpin dan tokoh masyarakat, baik sifatnya formal maupun informal;

3) Selalu mengkritisi masalah yang dihadapi sebagai buah dari suatu kebijakan publik dengan berbagai konsekuensinya;

4) Keberhasilan peran serta ditentukan oleh kualitas dan kuantitas informasi yang diperoleh, memanfaatkan informasi itu sebagai dasar bagi penguatan posisi daya tawar, dan menjadikannya sebagai pedoman dan arah bagi penentuan peran strategis dalam proses pembangunan;

5) Bagi Pemerintah, peran serta masyarakat itu merupakan sumber dan dasar motivasi dan inspirasi yang menjadi energi kekuatan bagi pelaksanaan tugas dan kewajibannya.

Sesuai dengan Pasal 70 UU No. 32 Tahun 2009

(1) Masyarakat memiliki hak dan kesempatan yang sama dan seluas-luasnya untuk berperan aktif dalam perlindungan dan pengelolaan lingkungan hidup.

(2) Peran masyarakat dapat berupa

a. pengawasan social

b. pemberian saran, pendapat, usul, keberatan, pengaduan; dan / atau

c. penyampaian informasi dan / atau laporan.

(3) Peran masyarakat dilakukan untuk: 
a. meningkatkan kepedulian dalam perlindungan dan pengelolaan lingkungan hidup;

b. meningkatkan kemandirian, keberdayaan masyarakat, dan kemitraan;

c. menumbuhkembangkan kemampuan dan kepeloporan masyarakat;

d. menumbuhkembangkan ketanggapsegeraan masyarakat untuk melakukan pengawasan sosial; dan

e. mengembangkan dan menjaga budaya dan kearifan lokal dalam rangka pelestarian fungsi lingkungan hidup. ${ }^{7}$

Peran serta masyarakat menjadi penting, karena peran serta masyarakat merupakan bagian dari prinsip demokrasi, yang salah satu prasyarat utamanya adalah adanya asas keterbukaan dan transparansi dengan 5 (lima) unsur utama (agar asas tersebut terpenuhi), yakni: Hak untuk mengetahui, Hak untuk memikirkan, Hak untuk menyatakan pendapat, Hak untuk mempengaruhi pengambilan keputusan dan Hak untuk mengawasi pelaksanaan keputusan.

\section{PENUTUP}

\section{A. Kesimpulan}

1. Manusia sebagai penguasa lingkungan hidup di bumi berperan besar dalam menentukan kelestarian lingkungan hidup. Manusia sebagai makhluk ciptaan Tuhan yang berakal budi mampu merubah wajah dunia dari pola kehidupan sederhana sampai ke bentuk kehidupan modern seperti sekarang ini. Namun sayang, seringkali apa yang dilakukan manusia tidak diimbangi dengan pemikiran akan masa depan kehidupan generasi berikutnya seperti tindakan Illegal Logging

2. Illegal logging dalam substansi UU Lingkungan, yakni UU No. 32 Tahun 2009 adalah adalah tindakan orang yang menimbulkan perubahan langsung atau tidak langsung terhadap sifat fisik, kimia, dan / atau hayati

\footnotetext{
${ }^{7}$ M. Hamdan, Tindak Pidana Pencemaran Lingkungan Hidup, Mandar Maju, Bandung, 2006, hal. 53
} 
lingkungan hidup sehingga melampaui kriteria baku kerusakan lingkungan hidup.

\section{B. Saran}

1. Melestarikan lingkungan hidup merupakan kebutuhan yang tidak bisa ditunda lagi dan bukan hanya menjadi tanggung jawab pemerintah atau pemimpin negara saja, melainkan tanggung jawab setiap insan di bumi. Setiap orang harus melakukan usaha untuk menyelamatkan lingkungan hidup di sekitar kita sesuai dengan kapasitasnya masing-masing. Sekecil apa pun usaha yang kita lakukan sangat besar manfaatnya bagi terwujudnya bumi yang layak huni bagi generasi anak cucu kita kelak

2. Penegakan Hukum Illegal Logging merupakan tanggung Seluruh Bangsa Indonesia, Pemerintah dan Masyarakat Umumnya demi terwujudnya Lingkungan yang Sehat dan Bersih.

\section{DAFTAR PUSTAKA}

Achmad Santosa, Membentuk Pemerintahan Peduli Lingkungan Dan Rakyat, Indonesian Center For Environmental Law, Jakarta, 2000.

Emil Salim, Ratusan Bangsa Merusak Satu Bumi, Buku Kompas, 2007.

Indro Sugianto, Manual Investasi Illegal Logging, Indonesian Center For Environmental Law, Jakarta, 2006.

M. Hamdan, Tindak Pidana Pencemaran Lingkungan Hidup, Mandar Maju, Bandung, 2006.

Rahmat Ruhayana, Partisikencana Dan Pelestarian Lingkungan Hidup, Mitra Gama Widya, Yogyakarta, 2008.

Sukardi, Illegal Logging Dalam Perspektif Hukum Pidana (Kasus Papua), Universitas Atmajaya Yogyakarta, 2005.

Suryanto dkk, Illegal Logging : Sebuah Misteri Dalam Sistem Pengrusakan Hutan Indonesia, Balai Litbang Kehutanan, Kalimantan, 2006.

Indonesia, UU No. 32 Tahun 2009 tentang Perlindungan Dan Pengelolaan Hidup 
238 ADIL : Jurnal Hukum Vol. 3 No.2

Indonesia, Inpres RI No. 4 Tahun 2005 tentang Pemberantasan Dan Penembangan Kayu Secara Ilegal Di Kawasan Hutan Dan Peredarannya Di Seluruh Wilayah Republik Indonesia.

"illegal logging" (http://noerdblog.wordpress.com/2011/06/12/peluanghambatan-dan-tantangan-pemberantasan-illegal-logging), di akses 10 September 2012.

"Penegakan Hukum Lingkungan"

(http://umum.kompasiana.com/2009/06/19/instrumen-instrumen penegakan-hukum-lingkungan-terhadap-pelanggaran-hukum-lingkunganhidup), diakses 12 Oktober 2012. 